\title{
Giuseppe Sanfratello
}

Giuseppe Sanfratello, PhD Fellow, Saxo Institute Giuseppe. Sanfratello got a M.A. in Musicology at the University of Palermo with a thesis on the Cretan singing traditions (rizitika and mandinadhes). He is currently enrolled as a Ph.D. fellow in Byzantine musicology at the University of Copenhagen, while conducting a research concerning the transmission of the Byzantine liturgical oral chant tradition in Sicily. In addition, he has received classical guitar music training at the Conservatoire of Palermo.

\section{A BYZANTINE CHANT COLLECTION FROM SICILY}

\section{A Collaboration between Copenhagen and Piana degli Albanesi (Palermo)}

The aim of this paper is to give an account of the collaboration between a collector of the Byzantine chant tradition of Piana degli Albanesi (Palermo)

in Sicily, namely fr. Bartolomeo Di Salvo, and the editorial board of the Monumenta Musicae Byzantinae, i.e. an institution under the aegis of the University of Copenhagen. Before describing precisely how this collaboration has developed, I will briefly introduce the "Sicilian-Albanian" oral liturgical chant tradition.

Among his publications are Oral performances in a (post)-literate society (Lund, 2016), The songs of the roots (forthcoming chapter on Cretan music, University of Vienna), Creative performance in the liturgy: a formulaic melodic language in the Sicilian-Albanian chant tradition (forthcoming, University of Joensuu, Finland), and several articles as chapters of his doctoral thesis. 


\section{Brief account of the chant repertoire ${ }^{1}$}

In Sicily, there is a village about 25 kilometers south-west of Palermo which is called Piana degli Albanesi. It has been established by a small group of Albanian refugees, when they reached the Sicilian coasts between 1482-85 in their flight from the Ottoman Turks. Since then, the Albanians, or rather the Arbëreshë, have maintained much of their own cultural, ethnic, linguistic and religious features, and so they have been able to preserve their own belonging to such specific ethnic group ${ }^{2}$. Also, this community can be considered the largest ethno-linguistic minority of Sicily ${ }^{3}$, together with the other communities living in Abruzzo, Molise, Campania, Apulia, Basilicata and Calabria.

Piana degli Albanesi (Hora e Arbëreshëvet) is indeed the main centre among the so-called "Sicilian-Albanian" colonies and it is also the See of the Byzantine Eparchy (i.e. Diocese), officially from the $1937^{4}$, under the Italo-Albanian Catholic Church. The Diocese itself includes the communes of Contessa Entellina, Palazzo Adriano, Mezzojuso and Santa Cristina Gela, although this last village does not retain the Greek rite anymore. ${ }^{5}$

One of the remarkable elements of the "Sicilian-Albanian" chant tradition is the cultivation of a vast musical heritage, thereby this repertoire consists of chants in ecclesiastical Greek for the celebration of the daily and yearly services and feasts of the Byzantine rite as well as a body of popular religious or devotional ('para-liturgical'6) songs. As a matter of fact, together with all the elements that constitute their own cultural identity, the Albanians of Sicily have brought, maintained and developed a specific liturgical chant tradition by adhering to the Eastern Byzantine rite. ${ }^{7}$ The priests and laypeople of the community have maintained this repertoire of chants, which has been handed down only by means of the oral transmission until the end of the $19^{\text {th }}$ century.

1 This paragraph is only a brief report of a wider study that is still ongoing as part of my PhD programme at the Saxo Institute, Univ. of Copenhagen.

2 Kellner 1972, p. 35.

3 Garofalo 2006, p. 12.

4 The constitution ‘Apostolica sedes' (issued by Pius XI 26 October 1937) granted the bishop of Piana full autonomy.

5 Even though Arbëreshë dialect has not been spoken in Mezzojuso and Palazzo Adriano since the early nineteenth century, the two communities have traditionally considered themselves to belong to the "Sicilian-Albanian" minority since they adhere to the Greek Byzantine rite. This second marker of ethnic and cultural identity is practised in four of the five villages; in Santa Cristina Gela the Roman rite is practised, as in the rest of Sicily. Since 1937 the Greek Catholic Church of the Albanians in Sicily has been led by the Eparchy of Piana degli Albanesi (earlier 'Piana dei Greci'), where the bishop resides. (see Garofalo \& Troelsgård 2016)

7 Ferrara 1985, p. 23. 


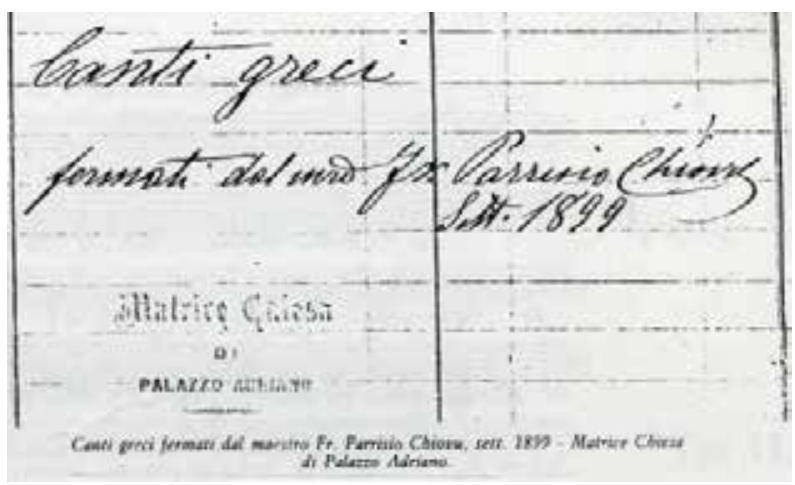

Fig. 1. A first musical transcription of some chants (in modern staff notation), which was found in 1986 by papas Jani Pecoraro (Palermo), with "1899" as a reporting date and "Palazzo Adriano" (i.e. one of the villages of the Diocese) as the place where it was transcribed by "Maestro fr. Parrisio Chiovu".

In 1899 we find the first musical transcriptions (see fig. 1) ${ }^{8}$ of a corpus of chants (see Hugues-Athanase Gaïsser ${ }^{9}, 1853-1919$ ), and since then several documents of this type have been produced.

Nevertheless, these specimens did not convey the entire musical repertoire but only some examples of chants, as well as some abridged set of melodies and texts of such tradition. Henceforth, priests and monks made several transcriptions on staff notation in the beginning of the twentieth century. The following is a list of the most important collectors and transcribers:

- fr. Gregorio Stassi ${ }^{10}$ (1870-1949), monk at Grottaferrata (Rome), born in Piana degli Albanesi, $\approx 1910$ ca.

- fr. Lorenzo Perniciaro (1899-1975) from Mezzojuso ${ }^{11}, \approx 1927-32$

- Francesco Falsone, ed. 1936, layman

- fr. Lorenzo Tardo (1883-1967), ed. 1938, monk at Grottaferrata and distinguished scholar of Byzantine music

- fr. Matteo Sciambra (1914-1967) from Contessa Entellina $\approx 1950-60$

Particularly, the manuscripts made by fr. Stassi and Falsone were fundamental sources in the collection of chants gathered by fr. Di Salvo between the 1950s and the early 1960s, which is the central subject of this paper.

8 Pecoraro 1986, p. 53.

9 He published the first scientific article on the chants of the Italo-Albanian tradition in Sicily (1905).

10 His chant collection is very important because it is the oldest chant collection (c. 1910), which "came to serve as a model for the rendition of the repertoire in staff notation for the later transcribers." (cf. Garofalo, "Father Bartolomeo Di Salvo and his transcriptions of the Byzantine Chants among the Albanians in Sicily", in Chants of the Byzantine Rite..., 2016).

11 Canti bizantini di Mezzojuso, vol. 1 ('I manoscritti di Papàs Lorenzo Perniciaro'), ed. Girolamo Garofalo, Palermo: Regione Siciliana, Assessorato ai Beni culturali 2001. 
Regarding the presence of these written, or rather "transcribed" sources in such communities marked by the phenomenon of the musical orality, it is indeed meaningful to look at the relationship between the two forms of transmission. Actually, the performance given by the cantors during the liturgies is totally based on oral structures and melodic formulae. ${ }^{12}$ They do not use musical scores nor transcriptions, but only some books or booklets reporting the lyrics of the chants, so that they can apply a certain group melodic formulae - transmitted through the oral tradition - to diverse texts of chants that may not retain their "original" melody anymore.

\section{Fr. Di Salvo and his collection}

Father Bartolomeo (see fig. 2) was born in Piana degli Albanesi in the province of Palermo in Sicily 1 August 1916; he took the vows of a monk 1 November 1937 and was ordained a priest 29 June $1940 .{ }^{13} \mathrm{He}$ also studied at the Abbazia greca di San Nilo in Grottaferrata (Rome), under the guidance of father Lorenzo Tardo, who founded a very famous chant school in the monastery, where they had the possibility to study the Byzantine chant tradition from medieval musical manuscripts. In fact, fr. Di Salvo was considered the successor of fr. Tardo.

Furthermore, some of his first scholarly publications ${ }^{14}$ appeared after an international congress for Sacred Music, which was held in Rome in 1950. As I mentioned earlier, he was the first collector who - between 1950-1960 - gathered the very first complete collection (Canti ecclesiastici della tradizione Italo-Albanese in Sicilia) providing musical transcriptions of the whole repertoire of chants of this still living tradition. In the same decade, fr. Di Salvo got in contact with the Monumenta Musicae Byzantinae (MMB, today within the Saxo Institute at the University of Copenhagen), an editorial programme and centre of research in Byzantine chant led by scholars ${ }^{15}$ of the University of Copenhagen, and eventually

12 Sanfratello, in press.

13 This paper is mainly based on a forthcoming publication Chants of the Byzantine Rite: The Italo-

Albanian Tradition in Sicily (Canti Ecclesiastici della Tradizione Italo-Albanese in Sicilia), edited by

G. Garofalo \& C. Troelsgård with assistance of G. Sanfratello, MMB, Subsidia V.1, Copenhagen 2016, in which it is possible to get more information on fr. Di Salvo's life and works.

14 Bartolomeo di Salvo: "La notazione paleobizantina e la sua trascrizione"; "La tradizione orale dei canti liturgici delle colonie Italo-Albanesi di Sicilia comparata con quella dei codici antichi bizantini”; in Higinio Anglès (ed.): Atti del congresso internazionale di Music Sacra (Roma, 2530 Maggio 1950), Tournai: Desclée \& Cie 1952; “La tradizione musicale bizantina delle colonie italo-albanesi di Sicilia e quella manoscritta dei codici antichi”, in Bollettino della Badia Greca di Grottaferrata, nuova serie 4, pp. 3-26: "Alcune tradizioni musicali liturgiche orientali e la tradizione scritta dei codici bizantini medioevali”, in Atti del Congresso internazionale di musiche popolari mediterranee e dei bibliotecari musicali (Palermo, 26-30 giugno1954), Palermo 1959, pp. 229-235.

15 Carsten Høeg (1896-1961), Henry Julius Wetenhall Tillyard (1881-1968), and Egon Joseph Wellesz (1885-1974) founded the institution in Copenhagen 1931. 
they agreed to publish the critical edition of this collection within the prestigious series issued by the MMB.

Such a collection was already being prepared for publication during the 1960s; it consists of 259 pages containing transcriptions of 484 items, such as whole chants, variants and analysis of formulaic (i.e. melodic) schemes. The ready-to-print films of the collection have resided in the archive of MMB since the early 1970s. The editorial process was actually brought to its present state in about 1965. It involved several changes regarding the structuring and numbering of the collection. A few faulty details probably needed corrections, but the main reason for the halt of the project was the missing introduction, in all likelihood the Sici-

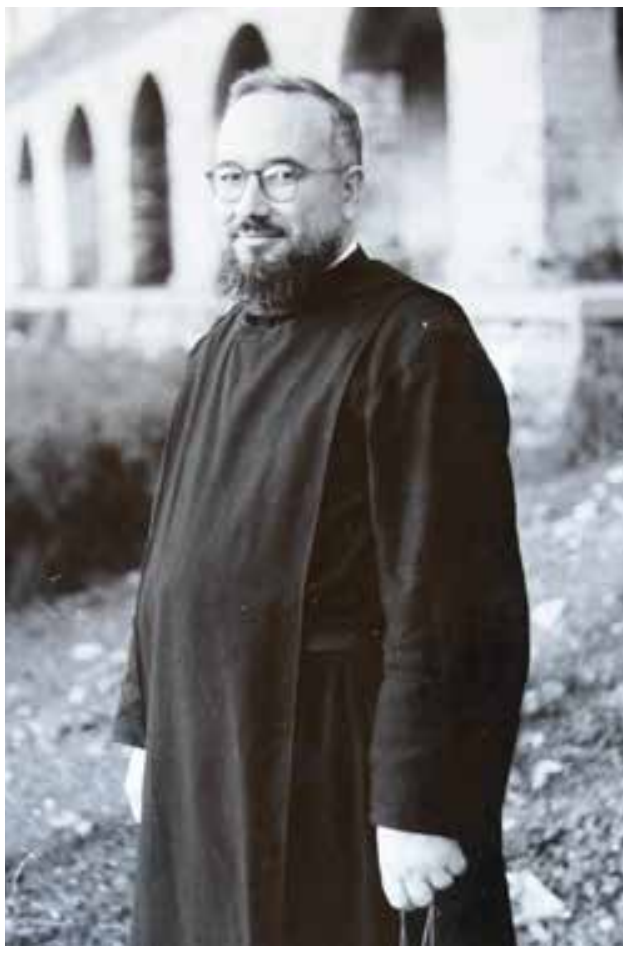

Fig. 2 Father Bartolomeo Di Salvo. The archive in Grottaferrata. lian monk never wrote it.

When, unfortunately, fr. Di Salvo fell ill, his collaboration with the editorial committee of the Monumenta Musicae Byzantinae was interrupted due to such force majeure. These pieces of information can mainly be derived from the correspondence between the then representatives of the MMB (Oliver Strunk, Henrik Glahn and Jørgen Raasted) and fr. Bartolomeo Di Salvo (Archive of the MMB), and from the official report from MMB to the Royal Danish academy of Sciences and Letters (1972): "We are still awaiting for the completion of the publisher's introduction". For more specific historical and ideological backgrounds for publishing the "Sicilian-Albanian" tradition, in relation to the editorial programme of the MMB, I must refer to the introduction to the edition written by Christian Troelsgård, in the forthcoming publication of this work ${ }^{16}$ :

Successive directors of MMB, first Oliver Strunk, and later Henrik Glahn, made repeated attempts to squeeze, so to speak, the missing introduction out of Di Salvo. Giving up hope of a publication in the near future, Glahn decided in 1972 to pay the outstanding bill for the production of print-ready films to publisher, Munksgaard, and he seems finally to have abandoned the project in 1973.

16 Cf. Troelsgård, "The Corpus of Italo-Albanian Chant and Monumenta Musicae Byzantinae", in Chants of the Byzantine Rite..., 2016. 
As a matter of fact, after fr. Di Salvo's death in 1986, his collection of chants was considered to be lost in Italy, and still today nobody knows where the original transcriptions written by him may have been kept. Nevertheless, in 1993, when the Editorial Board of the MMB held a meeting in Copenhagen under the direction of Jørgen Raasted, “the project surfaced again in the MMB programme”. ${ }^{17}$

\section{The "restored" collaboration between Denmark and Sicily}

In order to carry out such a fascinating editorial project, several contributions have been offered and diverse efforts have been made since its first conception in 1960s. Indeed, after more than fifty years, thanks to the collaboration arisen in 2000 between Girolamo Garofalo, researcher in ethnomusicology at the University of Palermo, and Christian Troelsgård, associate professor in Byzantine music and medieval studies at the Saxo Institute - as well as secretary of the MMB - this project has been restored. As a matter of fact, Garofalo - among other interests on Sicilian traditional music - has undertaken ethnomusicological research on the oral liturgical chant tradition of Piana degli Albanesi since the early 1990s. He has produced several publications ${ }^{18}$ and editions of CDs with audio recordings made during fieldwork, liturgies and celebrations in the Cathedral of Piana degli Albanesi (see fig. 3).

Unfortunately, due to the occurrence of a period of illness, the editorial project of fr. Di Salvo's collection, has yet again encountered an obstacle to its completion.

In the meantime, my own contribution - as a former student of Garofalo - to bring this project forward have started. Indeed, since I came to the University of Copenhagen to carry out my own research within the framework of the PhD programme at the Saxo Institute, under the supervision of Christian Troelsgård, I have started collaborating with him in order to try to complete the this editorial project.

Nevertheless, it has been very challenging to deal with some specific issues. For instance, what it is quite clear within the collection of musical transcriptions made by fr. Di Salvo that for each chant he included a series of sigla (see fig. 4), namely characters used to denote words such as "S", "F”, “M", "P", etc. As stated earlier, since fr. Di Salvo never sent his introduction to the volume to the editors of the MMB in Copenhagen, or probably never wrote it, these enigmatic letters have never been explained. Garofalo put in work to figure out what the meaning of such letters could have been, but only by putting together his recent writings 


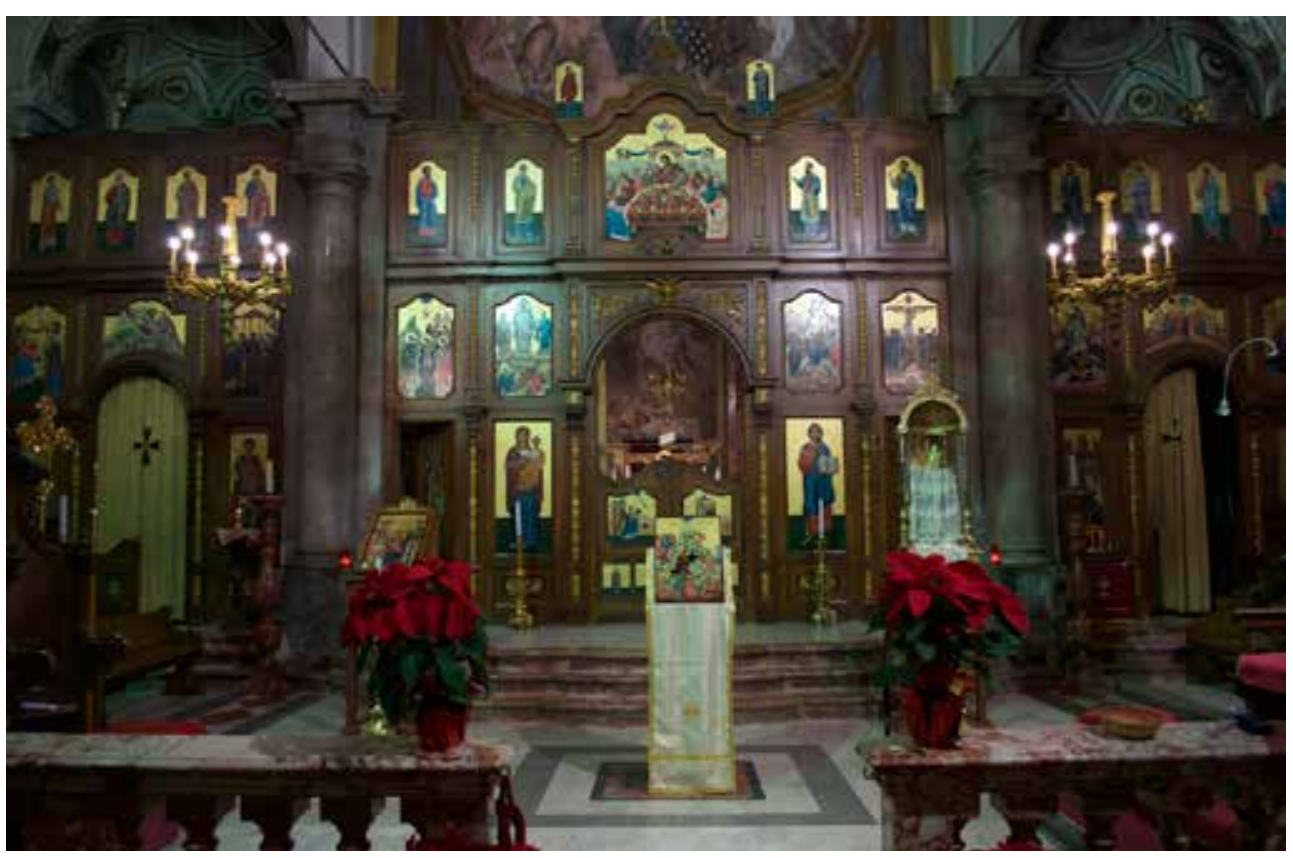

Fig. 3. The Cathedral of "San Demetrio Megalomartire di Tessalonica" in Piana degli Albanesi. Detail of the iconostasis. Own photo.

\section{Varianti}

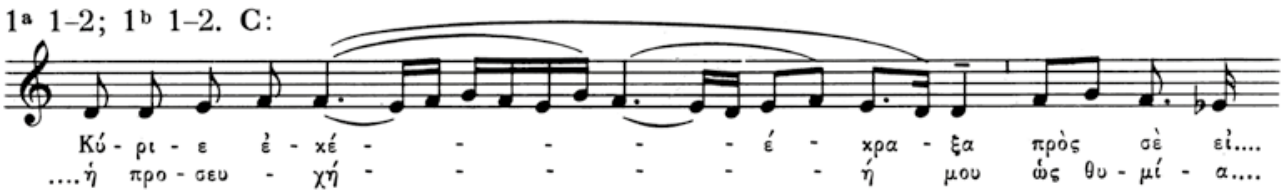

$1^{\text {a }} 3,5 ; 1^{\text {b }} 4$. M, C, P, Pa:

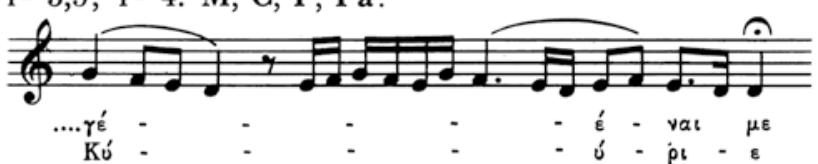

Fig. 4. An example of "Varianti" (i.e. melodic variants) included in the collection, in which some sigla are indicated (cf. no. 1, p. 6, in Chants of the Byzantine Rite, 2016).

and by producing some hypotheses, Troelsgård and I have been able to work on a complete index presenting the list of chants included in the collection, with a meticulous description of each sample, as well as an explanatory table dealing with the association between the "mysterious" series of sigla and the real meaning they convey.

Hence, it has been possible to realize that these characters are nothing but a series of abbreviations indicating the village or place of origin of the different versions of a single chant (e.g. "M" = Mezzojuso, "P" = Piana degli Albanesi, etc., see fig. 5), while some of the others indicate the source for a specific transcriptions 


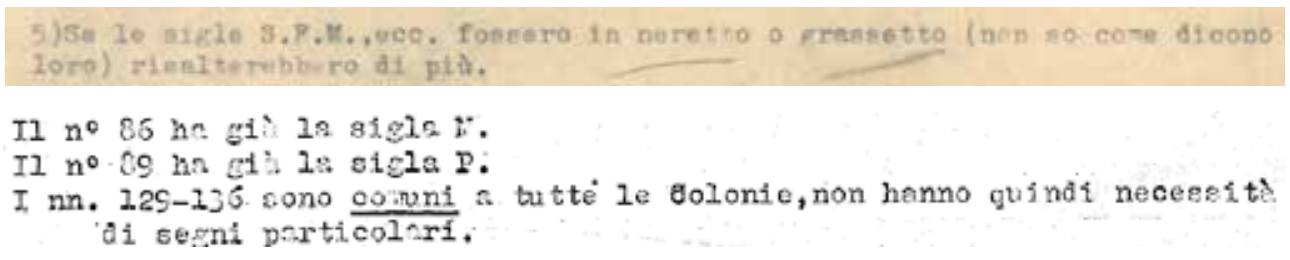

Fig. 5. These are two different clippings taken from the correspondence between fr. Bartolomeo di Salvo and the MMB, in which the Sicilian monk explains something about the meaning of the sigla, confirming that some of them relate to the precise locality where a variant of a chant has been developed.

(i.e. as in the case of the important source of fr. Gregorio Stassi, thereby "S" as the abbreviation or sigla included in the title).

Moreover, further evidence of such interpretation has been found in the archive of the MMB, where one can also find the original correspondence between fr. Bartolomeo Di Salvo and the then director(s) of the editorial programme. To provide an example, we have found some very specific indications given by fr. Di Salvo in a letter sent to the MMB (see fig. 5) ${ }^{19}$, in which he very specifically asked to put in "neretto o grassetto" (in "bold") some of the sigla ("S., F., M., ecc."), in order to highlight the sources from which he gathered the melodic tradition(s) to be included in his collection. Furthermore, we are also informed that those chants that do not retain any specific indications of sigla, are common among the colonies.

Thanks to this documentary material, we have also been able to find other elements for a reconstruction of a both striking and complicated collaboration between a monk from Sicily - living in a mountain village in the province of Palermo - and an academic institution in Denmark.

\section{Ethnomusicological approaches to "sister" musical traditions}

In the study of an orally transmitted chant tradition, the ethnomusicological perspective has advantages. For instance, some features of medieval music, as even in the case of the Gregorian chant, have been linked to the process of oral transmission and therefore analysed from ethnomusicological perspectives. ${ }^{20}$

Apart from the examination of melodic structures and of the historical development of chant traditions, the concept of "revival" is very fruitful. In The past is always present, ethnomusicologist Tore Lind offers the results of his fieldwork on the musical revival of the Byzantine chant at the Holy and Great Monastery of

19 The two letters were sent from Grottaferrata to the then director of MMB, professor Oliver Strunk, on February 8, 1964 and January 24, 1965.

20 Jeffery 1992 
Vatopedi on Mount Athos. In particular, his research has focused on the meaning of the "past" in the musical performance of the monks of that community, and on how they conceive it while maintaining and "reviving" their own tradition.

The oral liturgical Byzantine chant tradition of Piana degli Albanesi is a clear example of music heritage, which has survived thanks to the strength of the oral memory and transmission, at least until the end of the $19^{\text {th }}$ century when it was written down - although not entirely - for the sake of "fixed" safeguarding. Accordingly, I have had the opportunity to compare the actual state of the - still daily orally performed - tradition with some of the musical sources listed above reporting the "written" side of such repertoire. Indeed, it has been striking to figure out how the oral tradition continues to develop and create melodic microvariations despite the written transcriptions. This indicates that the cantors do not use them.

Together with the comparative analysis between the actual repertoire of the "Sicilian-Albanian" community and some late-medieval musical sources, which I am conducting within the framework of my Ph.D., it is also necessary to take into account other examples of "regional" repertoires that may have had a certain role in the development of the former as well as to strengthen the methodology involved in such study. I am planning to collect documentary material (audio-video recordings, musical transcriptions, interviews, etc.) on a research stay in the islands of Corfu and Zakynthos, in order to compare the two oral Byzantine chant traditions, i.e. the "Sicilian-Albanian" and the Ionian, that can be deemed "sister traditions" due to some musical features (e.g. the use of polyphonic singing in a repertoire that is usually based on monophony). These will be described in detail as soon as my analysis is concluded. Worth mentioning is the study offered by the Greek ethnomusicologist Markos Dragoumis, who has also dealt with the oral chant traditions of the Ionian islands. As a collector of folk music in Greece - on par with the work of father Bartolomeo Di Salvo in Piana degli Albanesi Dragoumis presents an anthology containing representative melodies from the church music tradition mainly of Zakynthos (with musical transcriptions). Dragoumis also reports a short history of the development of the oral tradition, trying in this way to paint a picture of the Ionian ecclesiastical repertoire as it has been orally conveyed to the present day. Further analyses might be able to provide updated information on the current state of the Ionian tradition and results that may be able to confirm the hypothesis of the similarities between the "SicilianAlbanian" and the Ionian chant tradition. ${ }^{21}$ 


\section{Current fieldwork and missing "chapters"}

It is indeed a great pleasure to see how, after several obstacles have been tackled and almost sixty years have passed, this remarkable editorial project has reached its publication. Without doubt, the edition of the chant collection of fr. Di Salvo is a first important step in the field of the scholarly studies regarding the "SicilianAlbanian" tradition. Certainly, more results might well be achieved in the study of it.

Concerning the actual state of the chant tradition, I myself have also carried out extensive ethnomusicological fieldwork in Piana degli Albanesi. I have recently ${ }^{22}$ had the opportunity to record the current condition of the repertoire. After a preliminary analysis of the collected data it is possible to prove that the chants have been maintained with strikingly few changes and micro-variations, especially if one compares them to the field recordings made by Sicilian ethnomusicologist Ottavio Tiby in 1952-53 ${ }^{23}$. This is an outstanding result, especially if one considers that neither the priests nor the congregation of faithful have ever had access to this collection of musical transcriptions.

Although Di Salvo's chant collection seemed to be lost in Italy after the editorial project was abandoned in 1973, it was very well preserved in the archive of the MMB in Copenhagen. As has been explained above, it took a while for it to reemerge from the bottom of a shelf in 1993 when the project was recovered by the previous editorial board. Moreover, there might be still some missing "chapters" to be written on the development of such fascinating musical tradition, especially because we still need to figure out, or perhaps to hypothesize, what happened to this chant repertoire over the last five centuries as well as to bare its intrinsic features. These questions and others, which may arise from the comparative analysis of this oral chant repertoire with late-medieval musical manuscripts, will have to be addressed in a number of dedicated papers focused on the nature, history, development and changes of this tradition.

Finally, the forthcoming publication of Di Salvo's collection within the MMB series is not just a sign of the "restored" collaboration between the University of Copenhagen and the Diocese of Piana degli Albanesi in Sicily, but also an important contribution for a deeper understanding of the medieval Byzantine music on the bases of the modern studies of the orally transmitted chant tradition. To this day, fr. Bartolomeo Di Salvo's work is the most comprehensive collection of the "Sicilian-Albanian" chant tradition accessible in print. Therefore, after almost sixty years, we are very much looking forward to having a copy of it in our hands.

22 In December 2014 and March-April 2015.

23 For detailed information about this collection of recordings, see Garofalo 2006. 


\section{Bibliography}

Di SAlvo, Bartolomeo

1952 - "La tradizione musicale bizantina delle colonie italo-albanesi di Sicilia e quella manoscritta dei codici antichi", in Bollettino della Badia Greca di Grottaferrata, N. S., VI: p. 3-26 (with musical examples), Grottaferrata. 1959 - "Alcune tradizioni musicali liturgiche orientali e la tradizione scritta dei codici bizantini medioevali”, in Atti del Congresso internazionale di musiche popolari mediterranee e dei bibliotecari musicali (Palermo, 1954), Palermo, p. 229-235.

FALsONE, Francesco

1936 - I canti ecclesiastici greco-siculi, Cedam, Padova, pp. 342 (with musical examples).

FERRARA, Sotìr (Salvatore)

1985 - "La musica bizantina nella tradizione popolare delle comunità italoalbanesi", in Atti della Giornata Culturale sul tema "P. Lorenzo Tardo e la musica bizantina” (25 Agosto 1985), Associazione culturale «Nicolò Chetta», Contessa Entellina (Pa), pp. 22-33.

GAÏssER, Hugues-Athanase

1905 - "I canti ecclesiastici italo-greci", in Atti del Congresso Internazionale di Scienze Storiche, Roma, 1-9 aprile 1903, VIII: pp. 107-123 (con esempi musicali); pubblicato anche in «Rassegna Gregoriana», IV, fasc. 9-10, Roma. Garofalo, Girolamo

2001 - Canti bizantini di Mezzojuso, vol. 1 ('I manoscritti di Papàs Lorenzo Perniciaro'), ed. Girolamo Garofalo, Palermo: Regione Siciliana, Assessorato ai Beni culturali 2001.

2006 a - "I canti bizantini degli arbëreshë di Sicilia. Le registrazioni di Ottavio Tiby (Piana degli Albanesi 1952-’53) e l'odierna tradizione”, in EM2: Musica e Religione, II/2: 11-65, Rivista degli Archivi di Etnomusicologia dell'Accademia Nazionale di Santa Cecilia, Squilibri editore, Roma.

2006 b - "Father Bartolomeo Di Salvo and his transcription of the Byzantine chants among the Albanians in Sicily”, in The current state of Byzantine musical studies after 75 years of Monumenta Musicae Byzantinae. Copenhagen, 16-17 giugno 2006, Grottaferrata (RM): Bollettino della Badia Greca di Grottaferrata (vol. 3), Acts of the International Conference "Monumenta Musicae Byzantinae 75th anniversary”, held at the Carlsberg Academy, pp. 93-116.

Garofalo, Girolamo - Troelsgård, Christian

2016 - Chants of the Byzantine Rite: The Italo-Albanian Tradition in Sicily (Canti Ecclesiastici della Tradizione Italo-Albanese in Sicilia), edited by G. Garofalo \& C. Troelsgård with assistance of G. Sanfratello, MMB, Subsidia V.1, Copenhagen, Forthcoming 2016. 
JEFFERY, Peter

1992 - Re-Envisioning Past Musical Cultures: Ethnomusicology in the Study of Gregorian Chant. Chicago: University of Chicago Press.

KELLNER, Heidrun

1972 - Die albanische Minderheit in Sizilien: eine ethnosoziologische Untersuchung der Siculo-Albaner, dargestellt anhand historischer und volkskundlicher Quellen sowie eigener Beobachtung in Piana degli Albanesi, Wiesbaden: Otto Harassowitz 1972 (Albanische Forschungen, 10).

Lind, Tore Tvarnø 2012 - The Past Is Always Present. The Revival of the Byzantine Musical Tradition at Mount Athos, Europea: Ethnomusicologies and Modernities Series, No. 13, The Scarecrow Press, Lanham.

Mele, Giampaolo - Sassu, Pietro (edited by) 1993 - Liturgia e paraliturgia nella tradizione orale, Universitas, Cagliari. Pecoraro, Giovanni 1986 - "Melurgia bizantina dei Siculo-Albanesi”, in Oriente Cristiano, XXVI, 4: pp. 51-57 (with musical examples), Palermo.

SANFRATELLO, Giuseppe in press - "Creative performance in the liturgy: a formulaic melodic language in the Sicilian-Albanian chant tradition”, in Creating Liturgically: Hymnography and Music, proceedings of the Sixth International Conference on Orthodox Church Music, University of Eastern Finland, Joensuu, Finland, 7-13 June 2015, edited by Ivan Moody and Maria Takala-Roszczenko.

SCIAMBRA, Matteo

1965 - "Caratteristiche strutturali dei canti liturgici della tradizione degli Albanesi di Sicilia”, in Rivista di Studi Bizantini e Neoellenici, N. S., 2-3: p. 309-320 (with musical examples).

TARDO, Lorenzo

1938 - L'antica melurgia bizantina nella interpretazione della scuola monastica di Grottaferrata, Scuola Tipografica Italo Orientale “S. Nilo”, Grottaferrata (Roma), with musical examples.

TiBy, Ottavio

1938 - La musica bizantina. Teoria e Storia, Fratelli Bocca Editori, Milano. $\triangle$ РАГОҮМНг, Ма́рко

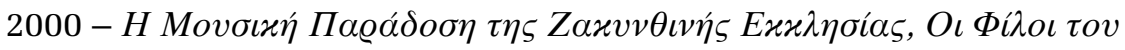

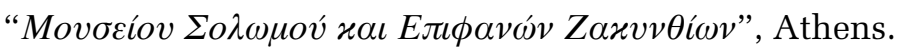




\section{English abstract}

The aim of this paper is to give an account of the collaboration between a collector of the Byzantine chant tradition of Piana degli Albanesi (Palermo) in Sicily, fr. Bartolomeo Di Salvo, and the editorial board of the Monumenta Musicae Byzantinae, i.e. an institution under the aegis of the University of Copenhagen.

Bartolomeo Di Salvo (1916-86), a Catholic monk of Byzantine Rite, gathered between 1950-1960 the most complete collection of this late-medieval and still living musical tradition, handed down over the last five centuries only by means of the oral transmission. In the same decade, fr. Di Salvo got in contact with the $\mathrm{MMB}$, and eventually they agreed to publish the critical edition of this collection. After more than fifty years, the updated and revised version of the edition of this meaningful collection is finally being published by the MMB. 